\title{
Molecular Characterization of Anisakis typica (Nematoda: Anisakidae) from the Mediterranean Sea Coasts of Turkey: First Mitochondrial rrnS Sequence Data
}

\author{
Gökmen Zafer PEKMEZCI* $\quad$ Ertan Emek ONUK \\ Department of Aquatic Animal Diseases, Faculty of Veterinary Medicine, University of Ondokuz Mayis, 55200 Kurupelit Samsun, Turkey
}

How to cite: Pekmezci, G.Z.\& Onuk, E.E. (2020). Molecular Characterization of Anisakis typica (Nematoda: Anisakidae) from the Mediterranean Sea Coasts of Turkey: First Mitochondrial rrnS Sequence Data. J. Anatolian Env. and Anim. Sciences, 5(2), 241-244.

Atıf yapmak için: Pekmezci, G.Z.\& Onuk, E.E. (2020). Türkiye'nin Akdeniz Kıyılarından Anisakis typica'nın (Nematoda: Anisakidae) Moleküler Karakterizasyonu: İlk Mitokondriyal rrnS Dizi Verileri. Anadolu Çev. ve Hay. Dergisi, 5(2), 241-244.

*Corresponding author's: Gökmen Zafer PEKMEZCI Department of Aquatic Animal Diseases, Faculty of Veterinary Medicine, University of Ondokuz Mayis, 55200 Kurupelit Samsun, Turkey.

$凶:$ zpekmezci@omu.edu.tr Mobile telephone : $+90(533) 3156857$ Telephone : $\quad+90(362) 3121919 / 2229$ Fax :+90362) 4576922
Abstract: There is no study about the molecular characterization of the mitochondrial $r r n S$ gene of Anisakis typica from the Turkish Mediterranean coasts. Thus, molecular characterization of the $r r n S$ gene of A. typica from Turkish waters is aimed for the first time in the present study. Ascaridoid marine nematodes were collected and morphologically identified by light microscope. Identified Anisakis type I larvae were randomly selected and molecularly analysed by Restriction Fragment Length Polymorphism (RFLP) for the internal transcribed spacer (ITS) region. Anisakis typica larvae identified by PCR-RFLP analyses were amplified and sequenced with both directions for the $r r n S$ gene. The $r r n S$ sequence of A. typica from the Mediterranean coasts of Turkey (MT395672) showed $99.80 \%$ identity (100\% query coverage) with $r r n S$ gene of A. typica (JX500052) from the Caribbean Sea, Atlantic Ocean. Between A. typica from the Mediterranean Sea (MT395672) isolate and the Caribbean Sea isolate differed by only one nucleotide (C-T, at alignment position 437). Pairwise genetic distance between the $r r n S$ sequence of $A$. typica herein and other A. typica from the Caribbean Sea was 0.002. Consequently, we determined the mitochondrial $\mathrm{rrnS}$ data of A. typica from the Mediterranean Sea in the present study for the first time. The valid genetic data (MT395672) reported here can be used to molecular identification of Anisakis species from the Mediterranean Sea and worldwide.

Keywords: Anisakis typica, Mediterranean Sea, molecular characterization, small subunit of rRNA (rrnS).

\section{Türkiye'nin Akdeniz Kıyılarından Anisakis typica'nın (Nematoda: Anisakidae) Moleküler Karakterizasyonu: İlk Mitokondriyal $r r n S$ Dizi Verileri}

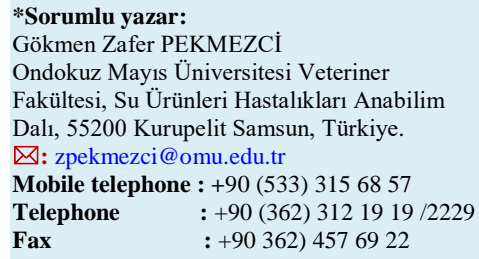

Öz: Türkiye Akdeniz kıyılarındaki Anisakis typica'nın mitokondriyal rrnS geninin moleküler karakterizasyonu hakkında bir çalışma bulunmamaktadır. Bu nedenle mevcut araştırmada Türk sularından izole edilen A. typica'nın $r r n S$ geninin moleküler karakterizasyonu amaçlanmıştır. Ascaridoid deniz nematodları toplandı ve morfolojik olarak 1şı mikroskobu ile teşhis edildi. Tanımlanan Anisakis tip I larvaları rastgele seçildi ve Sınırlayıcı Enzim Parça Uzunluk Çeşitliliği (RFLP) yöntemi ile internal transcribed spacer (ITS) bölgesi yönünden moleküler olarak analiz edildi. RFLP analizleri ile Anisakis typica olarak teşhis edilen larvaların $r r n S$ geni çoğaltıldı ve iki yönlü DNA dizi analizleri yapıldı. Türkiye'nin Akdeniz kıyılarından elde edilen A. typica'nın rrnS geni (MT395672) Atlantik Okyanusu Karayip Denizinden elde edilen A. typica'nın rrnS geni (JX500052) ile \%99,80 oranında (\%100 sorgu kapsamı) benzerlik gösterdi. Akdeniz'den A. typica (MT395672) izolatı ile Karayip Denizi izolatı arasında sadece bir nükleotit (C - T, hizalama pozisyonu 437) farklıydı. Buradaki A. typica'nın $r r n S$ dizisi ile Karayip Denizi'nden diğer A. typica arasındaki ikili genetik mesafe 0.002 'dir. Sonuç olarak bu çalışmada ilk kez Akdeniz'den A. typica'nın mitokondriyal $r r n S$ verilerini belirledik. Burada bildirilen geçerli genetik veri (MT395672), Anisakis türlerinin Akdeniz'den ve dünyadan moleküler tanımlanması için kullanılabilir.

Anahtar kelimeler: Akdeniz, Anisakis typica, küçük alt ünite rRNA (rrnS), moleküler karakterizasyon. 


\section{INTRODUCTION}

Adult nematodes of Anisakis Dujardin, 1845 are mainly found in the gastrointestinal canal of marine mammals. Different species of marine mammals and fish and squids serve as definite and intermediate or paratenic hosts, respectively. Until now based on molecular genetic markers such as nuclear and mitochondrial DNA, nine distinct Anisakis species have been reported in the world. Among the mitochondrial markers, the cytochrome oxidase I $(\operatorname{cox} 1)$, II $(\operatorname{cox} 2)$ and the small subunit of rRNA $(r r n S)$ genes are often prepared for molecular characterizations of Anisakis species. The specimen of $A$. typica has been widely distributed in definitive and intermediate or paratenic hosts at marine waters between $35-40^{\circ} \mathrm{N}$ to $36^{\circ} \mathrm{S}$ as geographic coordinates (Mattiucci \& Nassetti 2008, Mattiucci et al., 2018).

Both mitochondrial $\operatorname{cox} 2$ and nuclear ITS data of Anisakis species from marine fish were previously reported from coasts of Turkey (Pekmezci et al., 2014). Moreover, molecular characterization of $r r n S$ loci of only Hysterothylacium aduncum and Contracaecum overstreeti among ascaridoids nematodes of marine fish was made in the Turkish waters (Pekmezci \& Yardimci, 2019; Pekmezci, 2019). Up to date, there is no study about the molecular characterization of the mitochondrial $r r n S$ gene of A. typica from the Turkish Mediterranean coasts. Therefore, the molecular characterization of the $\operatorname{rrnS}$ gene of A. typica from Turkish waters is aimed for the first time in the current study.

\section{MATERIAL AND METHOD}

\section{Morphological examinations, PCR and RFLP}

analysis: Nematodes were collected from Merluccius merluccius in the Mediterranean coasts of Turkey. These were individually cut into three parts. The anterior and posterior parts were used for morphological identifications. The middle parts were used for DNA extractions using commercial kits. Nematodes were morphologically identified by light microscope according to Berland, (1961) and Petter and Maillard, (1988). Morphologically identified representative specimens were randomly selected and genetically analysed. The ITS regions of nuclear DNA were amplified using NC5/NC2 primers (Zhu et al., 1998). The ITS regions were then digested with HhaI and HinfI enzymes using RFLP analysis to identify the species (D'Amelio et al., 2000). All PCR amplicons and RFLP patterns were electrophoresed on $2 \%$ gel and visualized under UV illumination. The $r r n S$ gene of the mitochondrial DNA of the selected Anisakis species was amplified with MH3/MH4.5 primer pairs (D'Amelio et al., 2007).
DNA Sequencing and Genetic analysis: Selected three individuals were sequenced both directions with MH3/MH4.5 primer pairs using Sanger methods for the rrnS gene. We checked the sequence quality, assembled and then trimmed to remove primers in Geneious R11 (Kearse et al., 2012). The assembled sequence was blasted in GenBank database to examine the nucleotide similarity (Altschul et al., 1990). Obtained $r r n S$ data from Genbank were aligned by ClustalW in MEGA X multiple sequence alignments (Kumar et al., 2018) and adjusted manually. Pairwise distances were estimated using the K2P model in MEGA X (Kumar et al., 2018).

\section{RESULTS}

Ascaridoid nematodes were morphologically identified as third stage of Anisakis type I larvae. Some specimens of Anisakis larvae were classified as A. typica by RFLP analyses with HhaI and HinfI enzymes as previously described by D'Amelio et al., (2000). The amplified $r r n S$ gene of A. typica was produced $\sim 500$ bp in the PCR analyses. After DNA sequencing of $r r n S$ gene and trimmed to primers, the 494 bp length products were obtained in the present study. There were no intraspecific nucleotide differences detected within $r r n S$ gene of three representatives. Therefore, the $r r n S$ sequence of one representative was submitted to GenBank was given the accession number: MT395672. Nucleotide difference in the $r r n S$ sequences between A. typica from the Mediterranean Sea (MT395672) and the Caribbean Sea differed by one nucleotide $(\mathrm{C}-\mathrm{T}$, at alignment position 437) (Figure 1). Pairwise genetic distance between the $r r n S$ sequence of A. typica herein and other A. typica from the Caribbean Sea was 0.002 .

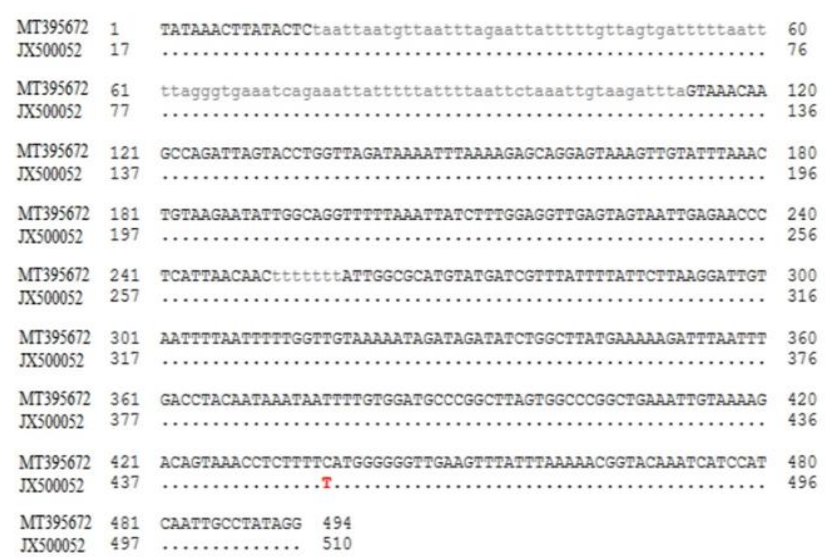

Figure 1. Nucleotide difference in the $r r n S$ sequences between $A$. typica from the Mediterranean Sea (MT395672) and the Caribbean Sea (JX500052) isolates. 


\section{DISCUSSION}

This study represents first data on the molecular characterization of the $r r n S$ gene region of $A$. typica isolated from the Mediterranean Sea. The sequence analysis of the rrnS loci of A. typica was firstly characterized from the Caribbean Sea, Atlantic Ocean by Mattiucci et al., (2014) and previously submitted as accession number JX500052 in GenBank database. A new valid $r r n S$ sequence of A. typica (accession number MT395672) in the present study was the second record in the GenBank database. Our $r r n S$ sequence of $A$. typica from the Mediterranean coasts of Turkey (MT395672) showed $99.80 \%$ identity (100\% query coverage) with $r r n S$ gene of A. typica (JX500052) from the Caribbean Sea, Atlantic Ocean (Mattiucci et al., 2014). Moreover, a search in GenBank database showed that $r r n S$ sequence of $A$. typica in the present study were ranged from $88.91 \%$ to $91.11 \%$ identical to $r r n S$ sequences of $A$. physeteris (JX500055), A. brevispiculata (JX500056), A. paggiae (JX500057), A. simplex x A. pegreffii (AB831878), A. nascettii (JX500054), A. ziphidarum (JX500053), A. pegreffii (LC222461) and A. simplex (AY994157). These results showed that mitochondrial $r r n S$ gene could be used effectively in the genetic distinction of Anisakis species. Pairwise genetic distance for mitochondrial $r r n S$ loci showed a very low-level variation among the Mediterranean Sea isolate of A. typica (MT395672) herein and the Caribbean Sea isolate of A. typica previously found (JX500052) (p distance $=0.002$ ). We considered the very low level of nucleotide differences $(0.2 \%)$ between those isolates of $A$. typica as intraspecific nucleotide differences because of the different geographical locations.

\section{CONCLUSION}

We determined the mitochondrial $r r n S$ data of $A$. typica from the Mediterranean Sea in the present study for the first time. Moreover, the new valid rrnS sequence (accession number MT395672) was the second record in the GenBank and this unique data can be also used to molecular identification of Anisakis species from the Mediterranean Sea and worldwide.

\section{CONFLICT OF INTEREST}

The authors declare that they have no competing interests.

\section{REFERENCES}

Altschul, S.F., Gish, W., Miller, W., Myers, E.W. \& Lipman, D.J. (1990). Basic local alignment search tool. Journal of Molecular Biology, 215, 403-410. DOI: 10.1016/S0022-2836(05)80360-2.

Berland, B. (1961). Nematodes from some Norwegian marine fishes. Sarsia, 2, 1-50.

D'Amelio, S., Mathiopoulos, K.D., Santos, C.P., Pugachev, O.N., Webb, S.C., Picanço, M. \& Paggi, L. (2000). Genetic markers in ribosomal DNA for the identification of members of the genus Anisakis (Nematoda: Ascaridoidea) defined by polymerase-chain-reaction-based restriction fragment length polymorphism. International Journal for Parasitology, 30(2), 223-226. DOI: 10.1016/s0020-7519(99)00178-2.

D'Amelio, S., Barros, N.B., Ingrosso, S., Fauquier, D.A., Russo, R. \& Paggi L. (2007). Genetic characterization of members of the genus Contracaecum (Nematoda: Anisakidae) from fish-eating birds from west-central Florida, USA, with evidence of new species. Parasitology, 134, 1041-1051. DOI: 10.1017/S003118200700251X.

Kearse, M., Moir, R., Wilson, A., Stones-Havas, S., Cheung, M., Sturrock, S., Buxton, S., Cooper, A., Markowitz, S., Duran, C., Thierer, T., Ashton, B., Meintjes, P. \& Drummond, A. (2012). Geneious Basic: An integrated and extendable desktop software platform for the organization and analysis of sequence data. Bioinformatics, 28(12), 1647-1649.

Kumar, S., Stecher, G., Li, M., Knyaz, C. \& Tamura, K. (2018). MEGA X: Molecular evolutionary genetics analysis across computing platforms. Molecular Biology and Evoluation, 35, 15471549. DOI: $10.1093 / \mathrm{molbev} / \mathrm{msy096}$.

Mattiucci, S., Cipriani, P., Levsen, A., Paoletti, M. \& Nascetti, G. (2018). Molecular epidemiology of Anisakis and Anisakiasis: an ecological and evolutionary road map. Advances in Parasitology, 9, 93-263. DOI: 10.1016/bs.apar.2017.12.001.

Mattiucci, S. \& Nascetti, G. (2008). Advances and trends in the molecular systematics of anisakid nematodes, with implications for their evolutionary ecology and host-parasite coevolutionary processes. Advances in Parasitology, 66, 47-148. DOI: 10.1016/S0065308X(08)00202-9.

Mattiucci, S., Cipriani, P., Webb, S. C., Paoletti, M., Marcer, F., Bellisario, B., Gibson, D. \& Nascetti, G. (2014). Genetic and morphological approaches distinguish the three sibling species of the Anisakis simplex species complex, with a species designation as Anisakis berlandi n. sp. for A. simplex sp. C (Nematoda: Anisakidae). Journal of Parasitology, 100, 199-214. DOI: 10.1645/12120.1 .

Pekmezci, G.Z. (2019). Molecular characterization of Hysterothylacium aduncum (Nematoda: Raphidascarididae) larvae infecting Merlangius merlangus euxinus (Linnaeus, 1758) from the Turkish Black Sea coast based on mitochondrial small subunit ribosomal RNA gene analysis. Etlik 
Veteriner Mikrobiyoloji Dergisi, 30(1), 64-69. DOI: $10.35864 /$ evmd.562427.

Pekmezci, G.Z., Onuk, E.E., Bolukbas, C.S., Yardimci, B., Gurler, A.T., Acici, M. \& Umur, S. (2014). Molecular identification of Anisakis species (Nematoda: Anisakidae) from marine fishes collected in Turkish waters. Veterinary Parasitology, 201, 82-94. DOI: 10.1016/j.vetpar.2014.01.005.

Pekmezci, G.Z. \& Yardimci, B. (2019). On the occurrence and molecular identification of Contracaecum larvae (Nematoda: Anisakidae) in Mugil cephalus from Turkish waters. Parasitology Research, 118(5), 1393-1402. DOI: 10.1007/s00436-019-06278-x.

Peter, A.J. \& Maillard, C. (1988). Larves d'ascarides parasites de poisons en Mediterranee occidentale. Bulletin du Museum National d'histoire Naturelle, 10 (sect. A), 347-369.

Zhu, X., Gasser, R.B., Podolska, M, \& Chilton, N.B. (1998). Characterization of anisakid nematodes with zoonotic potential by nuclear ribosomal DNA sequences. International Journal for Parasitology, 28, 1911-1921. DOI: 10.1016/s0020-7519(98)00150-7. 